\title{
Determinants of cross-cultural adjustment among expatriate employees: The role of personality
}

\section{Ekta Sharma}

Assistant Professor and Coordinator \& Head, MBA-Programmme, AM School of Management, Ahmmedabad University, India

\begin{abstract}
The present paper examined the personality of the Indian expatriates. Along with the Multi personality questionnaire to assess personality, three levels of adjustment were also used. This paper focuses on such personal characteristics, like cultural empathy, open mindedness etc., as a personality characteristic that is expected to either facilitate or impede cross-cultural adaptation. In this research the Multi-culture personality questionnaire is administered on 340 expatriates out of which, 180 are from US and 160 are from Japan. The sample includes 204 males and 136 females. This study can also be helpful in the recruitment and selection process of the candidates for expatriation. Cultural empathy turns out to be the predictor of personal adjustment. Flexibility is strongly correlated to the social adjustment. Females are low on emotional stability \& social Initiative.
\end{abstract}

Keywords: Expatriates, cultural empathy, open-mindedness, social initiative, emotional stability, flexibility

GEL Classification Code: J50; M12; M54

\section{INTRODUCTION}

In the era of globalization, the world has come closer and the national boundaries are no more the limiting boundary for the talent to permeate. The Multi- National Company's (MNC), when recruit and select people for the organization, expect that the candidate can be located in any of the subsidiaries, be it in any part of the world. In today's age of multicultural, global organizations, superiors and subordinates who must work together are often from different cultures (Mendenhall, Dunbar and Oddou 1987). International human resource experts agree it is imperative for multinational companies (MNCs) to attract, select, develop, and retain employees who can live and work effectively outside of their own national borders (Adler\&Bartholomew 1992, Black,Gregersen\&Mendenhall 1992, Mendenhall \& Oddou ;1985, Stroh \& Caligiuri 1998,Tung 1988, Tung \& Miller 1990). These employees, who are sent from a parent company to live and work in another country for a period ranging from two to several years, are colloquially referred to as 
"expatriates." The number of expatriates MNCs are sending on global assignments is increasing steadily (Laabs 1993,Stroh \& Dennis \& framer 1994). In order to adjust to a new culture and work efficiently, the expatriates need to accommodate their attitudes and behaviours to the new cultural context (Huang, Chi and Lawler 2005).

Expatriates represent a potential competitive advantage for multinational corporations. Expatriates carry out assignments such as facilitating the operation of foreign subsidiaries, establishing new international markets, spreading and sustaining corporate culture, and transferring technology, knowledge and skills (Brown, 1994;Klaus, 1995; Solomon, 1994).

The research has already shown that there are differences in the values held by people from various cultures around the world (Evans and Sculli 1981, Hofstede 1980, Hofstede and Bond 1984, 1988, Kelley, Whatley and Worthley 1987, Ralston, Cunniff and Gustafson in press, Ronen and Shenkar 1985, Tung 1991). Understanding the behavior patterns of individuals who are from different cultures is particularly salient for expatriate managers who not only must work with individuals from other cultures, but who also must work in a foreign culture (Mendenhall and Oddou 1985, Shaw 1990). To be effective in a foreign culture, expatriate managers must understand both the origin of their own behavior and the congruence of their behavior with that of individuals who are from the foreign culture (Black, Mendenhall and Oddou 1991, Internationalization 1989).

Personal characteristics are expected to facilitate or impede the formation of social networks, the ability to accomplish tasks and the expatriate's adjustment and performance (Stahl \& Caligiuri, 2005). Since it is easier to develop interpersonal relations with peers who come from similar cultures, and who are of similar status, it is important to understand personal characteristics of those who are able to span the cultural boundaries that may exist between the expatriate and local staff (Aycan, 1997; Black, Mendenhall \& Oddou, 1991; Harrison, Shaffer \& Bhaskar-Shrinivas, 2004).

This paper focuses on such personal characteristics, like cultural empathy, open mindedness etc., as a personality characteristic that is expected to either facilitate or impede cross-cultural adaptation.

In this research the Multi-culture personality questionnaire is administered on 340 expatriates out of which, 180 are from US and 160 are from Japan. The sample includes 204 males and 136 females. This study can also be helpful in the recruitment and selection process of the candidates for expatriation.

Taking into account expatriate personality traits and contextual factors related to personal, social and Professional adjustment in Japan \& United States (US), the present study contributes to the expatriate literature in four ways. First, the influence of expatriate personality traits on adjustment is examined using the Multicultural Personality Questionnaire (MPQ) instead of general personality scales that might not capture crosscultural adjustment (Van der Zee and Van Oudenhoven 2000). Second, the MPQ is extended from exploratory studies with real expatriates living and working in foreign countries i.e Japan \& US. Third, this study has purported to explore impact of the gender on the adjustment of expatriates; fourth, this study has further tried to analyze the relation between job satisfaction and personality traits.

\section{LITERATURE REVIEW}

Cross-cultural adjustment is the extent to which individuals are psychologically comfortable living outside of their home country (Black 1990, Black and Gregersen 1991). Cross-culturally adjusted expatriates "represent a more integrative approach to a new culture, (they) ... are open to the host culture, but integrate new behavior, norms and roles 
into the foundation provided by (their) home cultures" (Church 1982, p. 543). On the other hand, maladjusted expatriates are unable or unwilling to accept the host countries' behaviors, norms, and roles: Very simply, cross-cultural adjustment is "the individual's affective psychological response to the new environment" (Black 1990, p. 122).

Many scholars have added to the list of factors which influence cross-cultural adjustment (e.g., Arthur and Bennett 1995, Baker and Ivancevich 1971, Black et al. 1991, Black and Stephens 1989, Harvey 1985, McEvoy and Parker 1995).

Recently, the MPQ, which covers the personality traits of cultural empathy, openmindedness, social initiative, emotional stability, and flexibility, has been developed as a specific scale to measure expatriate adjustment (Van der Zee and Van Oudenhoven 2000). In reviewing literature, it was found that surprisingly few scholars have focused on expatriate adjustment in Japan (Black 1988; Napier and Taylor 1995, 2002). A study by Black (1988) indicates that the work adjustment of 67 American Organizational Expatriates was related to work role ambiguity and discretion, and general adjustment to association with host nationals and the adjustment of their families. While examining a variety of adjustment issues confronted by 30 female expatriates in Japan, Napier and Taylor (1995) found that their ages and Japanese language skills were important dimensions of successful work adjustment. For these female expatriates, housing and health care were the most difficult aspects of non-work-related adjustment. A comparative study of female expatriates in China, Japan, and Turkey several years later provided largely similar results (Napier and Taylor 2002).

Raduan Che Rose, Subramaniam Sri Ramalu,Jegak Uli,Naresh Kumar (2010) in the article, "Expatriate Performance in International Assignments: The Role of Cultural Intelligence as Dynamic Intercultural Competency", investigates the effects of dynamic intercultural competency of cultural intelligence and its dimensions on expatriate job performance.

\section{HYPOTHESIS}

1. The research has shown that women overall tend to be higher in empathy toward different ethnic/cultural groups (Cundiff \& Komarraju, 2008; Wang et al., 2003; Batson etal, 1996; Gault \& Sabini,2000; Lennon \& Eisenberg, 1987; Macaskill et al. 2002; Schieman \& Van Gundy, 2000). Thus, hypothesis examines the following: Hypothesis 1: Females have more Cultural empathy differences than will males.

2. Women are less emotionally stable than men (e.g., Schmitt \& Shackelford, 2008) Hypothesis 2: Females are low on emotional stability than males.

3. Women have, on average, better social skills and are more empathic and self-aware than men (Harvey, 1997; Martin et al., 1998; Nicholson, 2000; Van Velsor et al., 1993; Westwood et al., 1994). These characteristics will help women to learn more quickly than men how to establish and maintain relationships in the host country. Hypothesis 3: Females are higher on Social initiative than males.

\section{MetHOD}

\section{Respondents}

The questionnaire was sent to 500 expatriates but only 340 were returned, making for an overall response rate of $68 \%$. The sample of 340 respondents consisted of expatriates to Japan (160) and U.S (180). Of the respondents, 204 were male and 136 were female.

\section{Instruments}


A questionnaire was constructed that consisted of the following sections: biographical information, the Multicultural Personality Questionnaire, scales for personal adjustment and social support. The final section assessed respondents' professional adjustment.

\section{Biographic information}

In the first section respondents were asked to provide their name, address, nationality, date of birth, occupation, company, gender.

\section{The Multicultural Personality Questionnaire (MPQ)}

The Multicultural Personality Questionnaire (MPQ) is a personality assessment questionnaire that describes behavior when one is interacting with people from different cultures. The MPQ may be used to predict how easily people are likely to adjust to other cultures and come to feel at home with them. In the current study, the MPQ (Van der Zee and Van Oudenhoven, 2000, 2003) consisted of 78 items spread over five dimensions.

a. Cultural empathy

This scale assesses the capacity to identify with the feelings, thoughts and behavior of individuals from different cultural backgrounds. Cultural empathy, also referred to as sensitivity (Hawes and Kealey 1981), is an often mentioned aspect of multicultural effectiveness (e.g. Ruben 1976; Arthur and Bennett 1995).

\section{b. Open-mindedness}

This scale assesses people's capacity to be open and unprejudiced when encountering people outside of their own cultural group and who may have different values and norms. This ability, just like cultural empathy, seems vital to understanding the rules and values of other cultures and to coping with them in an effective manner.

Open-mindedness refers to an individual's open, unprejudiced attitude to out-group members and different cultural values (Arthur and Bennett 1995).

\section{c. Social Initiative}

Social initiative denotes people's tendency to approach social situations actively and to take initiative. This determines the degree to which they interact easily with people from different cultures and make friends within other cultures.

Social initiative is a tendency to stand out in a different culture, establish contact and be active (Van der Zee and Van Oudenhoven 2000). Expatriates who make social initiatives tend to be successful at living and working in foreign countries.

\section{d. Emotional stability}

This scale assesses the degree to which people tend to remain calm in stressful situations. Emotional stability refers to the tendency to remain calm rather than showing strong emotional reactions in stressful situations (Van der Zee and Van Oudenhoven 2001).

Helping expatriates cope with acculturative stress and adapt to a new cultural and work environment, emotional stability has been identified as a crucial dimension for overseas success across different functions (Church 1982).

\section{e. Flexibility}

Flexibility is the ability and tendency to adjust one's familiar behavioural strategies to different or more restricted circumstances within a foreign culture (Van der Zee and Van Oudenhoven 2001). Expatriates need to be flexible and able to shift easily from one strategy to another, as familiar ways of handling things might not work in new cultural environments (Arthur and Bennett 1995).

\section{Personal Adjustment, Satisfaction with Life}

This construct was measured by the Satisfaction with Life Scale (Diener, Emmons, Larsen, 
\& Griffin, 1985). The construct was measured by five items on a 5-point answering scale ranging from strongly agree [1] to strongly disagree [5].Examples of these items are: 'In most ways my life is close to my ideal' $(+)$ and 'The conditions of my life are excellent' $(+)$. Physical health was measured by the Rand 36-item Health Survey (Rand Health Sciences Program, 1992). The subscale for physical health consisted of six items, using a 5-point scale ( $\square \square=.76$ ). On the first of these items 'In general would you say your health is...' this scale ranged from poor [1] to excellent [5]. On the second item, 'During the past four weeks, how much of the time has your physical health or emotional problems interfered with your social activities (like visiting friends, relatives, etc.)?' this scale ranged from all of the time [1] to none of the time [5]. The other four items were scored on a scale ranging from definitely false [1] to definitely true [5].

Psychological Health was measured by two additional subscales of the Rand 36- item Health Survey, the mental health and the vitality scale, that were combined into one 9item scale. The scale ranged from none of the time [1] to all of the time [5].

\section{Professional Adjustment}

The professional adjustment of the respondents was assessed using the Job Satisfaction Survey which is a 36-item scale to assess employee attitudes about the job and aspects of the job (Spector, 1997). This scale was used because its items referred to a wide range of job aspects: rewards, opportunities for promotion, supervision, relationships at the workplace, the nature of work, and satisfaction with operating conditions.

Social Adjustment was assessed by social support by peers Items could be answered on a 4-point scale ranging from seldom or never [1] to very often [4]. The scale (17 items) was a shortened version of the 41-item Social Support List-Interaction (Van Sonderen, 1993).

\section{Hypothesis Testing}

The Independent sample test was conducted to test the hypothesis.

Hypothesis 1: Females have more Cultural empathy differences than males.

As per Table 4, significance level of Cultural Empathy is 0.00, which indicates that the mean is different. So, the hypothesis is accepted.

Hypothesis 2: Females are low on emotional stability than males.

The mean of Emotional stability of females (13.60) is less than that of males (14.14). (Refer Table 3). Hence, the hypothesis is accepted.

Hypothesis 3: Females are higher on Social initiative than males.

The mean score of females on Social Initiative is 13.13, which is lower than the scores of males (14). So, the hypothesis is rejected. (Refer Table 3).

\section{Results}

Table 1 \& 2 show descriptive statistics of Expatriates to US \& Expatriates to Japan respectively. The major differences between the expatriates posted to these two nations are:

CE for US (15.20) is more than Japan (14.69)

ES for US (14.80) is more than Japan (12.94)

Flexibility for US (12) is less than Japan (13)

Physical health is better in Japan (4.07) than US (3.57)

Social support is higher in Japan (3.08) than in US(2.71)

Job satisfaction is higher in Japan (4.05) than in US(3.67)

Copyright (C) 2012, Asian Business Consortium | GDEB 
INSERT TABLE $1 \& 2$.

Table 3. Shows the descriptive statistics of the variables based on gender, where " 0 " denotes males \& " 1 " denotes females.

Hypothesis 2 is accepted and hypothesis 3 is rejected on the basis of this table. Three variables- Cultural empathy, emotional stability \& Social Initiative have difference of one or more than one in the means of males \& females.

\section{INSERT TABLE 3}

Table 4, shows, results of Independent sample t-test, to find out the difference in the means of the sample based on the gender.

For Cultural Empathy, ES, SI and Satisfaction With life, Significance level is 0.00 , so the mean is different

OM Significance level is .074, F Significance level is 0.493, Psychological Significance level is 0.644 , Social Support Significance level is 0.638, Job Satisfaction Significance level is 0.977 , so the mean is same

\section{INSERT TABLE 4}

Table 5 shows the correlations between the variables under study. Job Satisfaction is significantly correlated to the personality variables, except OM \& SI. The adjustment variables like satisfaction with life, social support \& psychological health, also have significant relation with the personality variables.

\section{NSERT TABLE 5}

\section{Discussion}

The current study is focused on the study of the personality of the expatriates posted to US \& Japan by using Multicultural Personality Questionnaire and also their personal, social \& professional adjustment

First it was observed that among sub factors of MPQ scale, the highest correlation is between open-mindedness and Flexibility (.429). The person, who is flexible in his approach, could be unprejudiced towards people from other cultures and accept the differences easily.

Second, it was observed that the MPQ scales could significantly predict all three facets of personal adjustment: satisfaction with life, physical health, and psychological well-being. The strongest relationship was found between cultural empathy and personal adjustment. This stands true, as it is easy for expatriate to adjust in any nation, if he has understanding of others' culture.

Third, with regard to the relationship between job satisfaction and the MPQ scales, Flexibility seems to be a significant predictor (.266). The expatriate who scores high on this dimension may easily adjust his or her behavior to the different working conditions in the host country. So, this factor should be taken into consideration while selecting an expatriate. The importance of reaching a satisfactory level of well-being at work should not be underestimated. Job satisfaction is an important predictor of commitment and turnover (e.g., Lee, Mitchell, Wise, \& Fireman, 1996).

Fourthly, social adjustment which was measured by the variable -social support by peers. Flexibility is strongly correlated to the social support factor. Besides this, cultural empathy 
also has high correlation with the social support by peer. Surprisingly, the dimension of social initiative did not appear as a significant predictor of social support. We can attribute this deviation to the assumption that, in intercultural interactions, lack of neuroticism, flexibility and being sensitive to other persons' perceptions and intentions is more critical to building up a satisfactory social network than taking an active approach in social interactions. The importance of cultural empathy as a determinant of social support in the host country implies that it may be desirable to focus training efforts on this dimension.

Fifthly, if we observe the means of the sub-factors of MPQ scale for Expatriates in US, we can infer that they score highest on Cultural Empathy (15.20) and second highest on Open mindedness (15). So, it is highly recommended that while the selection of expatriates to be posted to US, they should be checked for both these traits as the Job satisfaction of the sample expatriates is more than average (3.67), so their traits can be taken as benchmark for the selection procedure.

Sixthly, in case of Expatriates to Japan, they rank highest on open mindedness (15.31) and second on cultural empathy (14.69).

Seventhly, on basis of gender there is not much of a difference, so we can safely conclude that people with identified traits can be safely expatriated, irrespective of the gender.

\section{CONCLUSION}

Given the extraordinary high financial, relational, and emotional costs for expatriates (Black/Gregersen/Mendenhall 1992), their families (Caligiuri/Hyland/Joshi/ Bross 1998, Guzzo/Noonan/Elron 1994), and their organizations, pre-assessment of the personality of the prospective expatriate is a rational step. Based on this study, we can conclude that the personality characteristics of expatriates are indicator of job satisfaction, so, we can use this in expatriate selection systems. Selection systems for global assignments should include an assessment of personality at the very behest, in the selection process. Thus, the organizations are recommended to assess their potential expatriates for their personality characteristics.

\section{RefEREnCES}

Adler, N. J. \& Bartholomew, S. (1992), 'Managing Globally Competent People', Academy of Management Executive, 6 (3) August.

Arthur, W.and Bennett, W., (1995) The International Assignee: The Relative Importance of Factors Perceived to Contribute to Success, Personnel Psychology, 48, pp. 99-1 14.

Aycan, Z. (1997). Acculturation of expatriate managers: A process model of adjustment and performance. In Z. Aycan (Ed.), New approaches to employee management (expatriate management: Theory and research), vol. 4 (pp. 1 - 40). Greenwich,Connecticut7 JAI press.

Baker, J. C.and Ivancevich, J. M., (1971)The Assignment of American Executives Abroad: Systematic, 1 lap.hazard or Chaotic?, California Management Review, 13, pp. 39-44.

Black, J. S., (1988). Work Role Transitions: A Study of American Expatriate Managers in Japan. Journal of International Business Studies, 78, pp. 277-294.

Black, J.S. (1990). The relationship of personal characteristics with adjustment of Japanese expatriate managers. Management International Review, 30, 119-134.

Black, J. S., Gregersen, H. B., (1991). Antecedents to cross-cultural adjustment for expatriates in PacificRim assignments, Human Relations, 44, , pp. 497-515. 
Black, J. S./Gregersen, H. B.,/Mendenhall, M. E., Global Assignments: Successfully Expatriating and Repatriating International Managers, San Francisco: Jossey-Bass 1992.

Black, J. S., Mendenhall, M., Oddou, G., (1991). Toward a comprehensive model of international adjustment: An integration of multiple theoretical perspectives, Academy of Management Review, 16, pp. 291-317.

Black, J. S., Stephens, G. K., (1989) The influence of the spouse on American expatriate adjustment and intent to stay in Pacific Rim overseas assignments, Journal of Management, 15, (1989) pp.529-544.

Brown, M. (1994) 'The Fading Charms of Foreign Fields', Management Today, August: 48- 51.

Caligiuri, P. M./Hyland, M./ Joshi, A./Bross, A., A Theoretical Framework for Examining the Relationship Between Family Adjustment and Expatriate Adjustment to Working in the Host Country, Journal ofApplied Psychology, 83, 1998, pp. 598-614.

Church, A. (1982). Sojourner adjustment. Psychological Bulletin, 9, 540-572.

Cundiff, N. L., \& Komarraju, M. (2008). Gender differences in ethnocultural empathy and attitudes toward men and women in authority. Journal of Leadership \& Organizational Studies, 15, 5-15.

Diener, E., Emmons, R.A., Larsen, R.J., Griffin, S. (1985). The Satisfaction With Life Scale. Journal of Personality Assessment, 49, 71-75.

Evans and Sculli. (1981). "A Comparison of Managerial Traits in Hong Kong and the US." Journal of Occupational Psychology.

Gault BA, Sabini J. The roles of empathy, anger, and gender in predicting attitudes toward punitive, reparative, and preventative public policies. Cognition and Emotion. 2000;14:495-520.

Guzzo, R. A., Noonan, K. A.,/Elron, E., Expatriate Managers and the Psychological Contract, Journal of Applied Psychology, 79, 1994, p. 617-626

Harrison, D. A., Shaffer, M. A., \& Bhaskar-Shrinivas, P. (2004). Going places: Roads more and less traveled in research on expatriate experiences. In J. J. Martocchio (Ed.), Research in personnel and human resources management, vol. 22 (pp. 203 - 252). Greenwich, CT7 JAI Press.

Harvey, M. G.,( 1985). The Executive Family: An Overlooked Variable in International Assignments, Columbia Journal of World Business, 20, pp. 84-92.

Harvey, M. 1997. Dual-career expatriates: Expectations, adjustment and satisfaction with international relocation. Journal of International Business Studies, 28(3): 627-658.

Hawes, F. \& Kealey, D. J. (1981). An empirical study of Canadian technical assistance. International Journal of Intercultural Relations, 5, 239-258.

Hofstede, G. 1980. Motivation, Leadership, and Organization: Do American Theories Apply Abroad? Organizational Dynamics, Summer: 42-63.

Hofstede, G. \& Bond, M. 1984. Hofstede‘s culture dimensions: An independent validation using Rokeach's value survey. Journal of Cross-Cultural Psychology, 15: 417-433.

Hofstede, G. \& Bond, M. H. 1988. The Confucius connection: From cultural roots to economic growth. Organizational Dynamics, 16(4): 4-21.

Huang, C., Chi, S., and Lawler, J. (2005). The relationship between expatriates' personality traits and their adjustment to international assignments, International Journal of Human Resources Management, 16:9, 1656-1670. 
Kelley, L., Whatley, A., Worthley, R., 1987. Assessing the effects of culture on managerial attitudes: A three-culture test, Journal of International Business Studies, 18(2), pp. 17-31.

Klaus, K.J. (1995) 'How to Establish an Effective Export Program best Practices in International Assignment Administration', Employment Relations Today, 22(1): 59 -79.

Laabs, J., 1993. Rating the International Relocation Hot Spots, Personnel Journal, 72, p. 19.

Lee, T. W., Mitchell, T. R., Wise, L., \& Fireman, S. (1996). An unfolding model of voluntary turnover. Academy of Management Journal, 39, 5-36.

Lennon R, Eisenberg N. (1987).Gender and age differences in empathy and sympathy. In: Eisenberg N, Strayer J, editors. Empathy and its development. Cambridge, UK: Cambridge University Press; pp. 195-217.

Macaskill A, Maltby J, Day L. (2002) Forgiveness of self and others and emotional empathy. The Journal of Social Psychology. ;142:663-665.

Martin, J., Knopoff, K., \& Beckman, C. 1998. An alternative to bureaucratic impersonality and emotional labor: Bounded emotionality at The Body Shop. Administrative Science Quarterly, 43(2): 429-469.

McEvoy, G. \&Parker, B., (1995).Expatriate' Adjustment: Causes and Consequences in Selmer, J: (ed.) Expatriate Management, pp. 97-114.

Mendenhall, M. \&Oddou, G., 1985. The Dimensions of Expatriate Acculturation, Academy of Management Review, 10, pp. 39-47

Mendenhall, M., Dunbar, E., \& Oddou, G. (1987). Expatriate selection, training and career pathing: A review critique. Human Resource Management, 26(3), 331-345.

Napier, N.K., and Taylor, S. (1995), Western Women Working in Japan, Westport, CT: Quorum Books.

Napier, N.K., and Taylor, S. (2002), 'Experiences of Women Professionals Abroad: Comparison across Japan, China and Turkey,' International Journal of Human Resource Management, 13,837-851.

Nicholson, N. 2000. Managing the human animal. London: Texere.

Rand Health Sciences Program (1992). Rand 36-item Health Survey 1.0. Santa Monica, CA:Rand

Ralston, D. A., Cunniff, M. K., Gustafson, D. J., Cultural accommodation: The effect of language on the responses of bilingual Hong Kong Chinese managers, Journal of Cross-Cultural Psychology, (in press).

Ronen, S., Shenkar, O., 1985. Clustering countries on attitudinal dimensions: A review and synthesis, Academy of Management Review, 10, pp. 435 -454.

Ruben, B. D. 1976. Assessing communication competency for intercultural adaptation. Group \& Organization Studies, 1(3), 334-354

Schmitt, D. P, \& Shackelford, T. K. (2008). Big Five traits related to short-term mating: From personality to promiscuity across 46 nations. Evolutionary Psychology, 6, 246-282.

Schieman S, Van Gundy K. (2000)The personal and social links between age and selfreported empathy. Social Psychology Quarterly. ;63:152-174.

Shaw, J. B.,( 1990). A cognitive categorization model for the study of intercultural management, Academy of Management Review, 15, pp. 626-645.

Spector, P.E. (1997). Job satisfaction: application, assessment, cause, and consquences, Thousand Oaks, CA: Sage. 
Stahl, G., \& Caligiuri, P. (2005). The effectiveness of expatriate coping strategies: The moderating role of cultural distance, position level, and time on the international assignment. Journal of Applied Psycho logy, 90, 603-615.

Stroh, L, K.\& Caligiuri, P. M., 1998. Strategic Human Resources: A New Source for Competitive Advantage in the Global Arena, International Journal of Human Resource Management, 9, pp. 1-17.

Stroh, L. K., Dennis, L. E.\& framer, T. C., 1994. Predictors of Expatriate Adjustment, International;Journal of Organizational Analysis, 2, pp. 176-192.

Tung, R: L., The New Expatriates, Cambridge, MA: Bathnger 1988.

Tung, R. L \&Miller, E. L., 1990. Managing'in the Twenty First Century: The Need for Global Orientation, Management International Review, 30, pp. 5-18.

Tung, R. L., 1981. Selecting and training of personnel for overseas assignments, Columbia Journal of World Business, 16, pp. 68-78.

Van der Zee, K.I., \& Van Oudenhoven, J.P. (2000). The Multicultural Personality Questionnaire: A multidimensional instrument of multicultural effectiveness. European Journal of Personality, 14, 291-309

Van der Oudenhoven, J.P., Mol, S., and Van der Zee, K.I. (2003), 'Study of the Adjustment of Western Expatriates in Taiwan ROC with the Multicultural Personality Questionnaire,' Asian Journal of Social Psychology, 6, 159-170

Van Velsor, E., Taylor, S., \& Leslie, J. B. 1993. An examination of the relationship among self-perception accuracy, self-awareness, gender, and leader effectiveness. Human Resource Management, 32(2 \& 3): 249-263.

Westwood, R. I. \& Leung, S. M. 1994. The female expatriate manager experience. International Studies of Management and Organization, 24(3): 64-85.

Table 1: Expatriates to US

Descriptive Statistics

\begin{tabular}{|l|r|r|r|}
\hline & \multicolumn{1}{|c|}{ Mean } & Std. Deviation & \multicolumn{1}{c|}{ N } \\
\hline Cultural Empathy & 15.20 & 1.169 & 180 \\
OM & 15.00 & .897 & 180 \\
ES & 14.80 & .750 & 180 \\
SI & 13.40 & 2.584 & 180 \\
F & 12.00 & .897 & 180 \\
Satisfaction w ith life & 3.690 & .4306 & 180 \\
physical health & 3.5700 & .38164 & 180 \\
psychological health & 3.400 & .6460 & 180 \\
social support & 2.7100 & .39019 & 180 \\
job satisfaction & 3.6700 & .43780 & 180 \\
\hline
\end{tabular}


Table 2: Expatriates to Japan

Descriptive Statistics

\begin{tabular}{|l|r|r|r|}
\hline & \multicolumn{1}{|c|}{ Mean } & Std. Deviation & \multicolumn{1}{c|}{$\mathrm{N}$} \\
\hline Cultural Empathy & 14.69 & 1.493 & 160 \\
OM & 15.31 & 1.493 & 160 \\
ES & 12.94 & 1.482 & 160 \\
SI & 13.94 & 1.482 & 160 \\
F & 13.00 & 1.176 & 160 \\
Satisfaction w ith life & 3.66 & .463 & 160 \\
physical health & 4.07 & .776 & 160 \\
psychological health & 3.594 & .4180 & 160 \\
social support & 3.08 & .454 & 160 \\
job satisfaction & 4.05 & .495 & 160 \\
\hline
\end{tabular}

Table 3: Descriptive statistics of variables, based on gender

Group Statistics

\begin{tabular}{|ll|r|r|r|r|}
\hline & gender & $\mathrm{N}$ & Mean & Std. Deviation & $\begin{array}{c}\text { Std. Error } \\
\text { Mean }\end{array}$ \\
\hline Cultural Empathy & 0 & 204 & 15.20 & 1.466 & .103 \\
& 1 & 136 & 14.60 & 1.077 & .092 \\
\hline OM & 0 & 204 & 15.04 & 1.042 & .073 \\
& 1 & 136 & 15.30 & 1.442 & .124 \\
\hline ES & 0 & 204 & 14.14 & 1.692 & .118 \\
& 1 & 136 & 13.60 & 1.014 & .087 \\
\hline SI & 0 & 204 & 14.00 & 2.445 & .171 \\
& 1 & 136 & 13.13 & 1.475 & .126 \\
\hline F & 0 & 204 & 12.44 & 1.196 & .084 \\
& 1 & 136 & 12.52 & 1.082 & .093 \\
\hline Satisfaction w ith life & 0 & 204 & 3.79 & .413 & .029 \\
& 1 & 136 & 3.50 & .438 & .038 \\
\hline physical health & 0 & 204 & 3.87 & .715 & .050 \\
& 1 & 136 & 3.71 & .520 & .045 \\
\hline psychological health & 0 & 204 & 3.481 & .6337 & .0444 \\
& 1 & 136 & 3.507 & .4227 & .0362 \\
\hline social support & 0 & 204 & 2.90 & .520 & .036 \\
& 1 & 136 & 2.87 & .354 & .030 \\
\hline job satisfaction & 0 & 204 & 3.85 & .452 & .032 \\
& 1 & 136 & 3.85 & .571 & .049 \\
\hline
\end{tabular}


Table 4: Independent sample T-test

\begin{tabular}{|c|c|c|c|c|c|c|c|c|c|c|}
\hline \multicolumn{11}{|c|}{ Independent Samples Test } \\
\hline & & \multicolumn{2}{|c|}{$\begin{array}{c}\text { Levene's Test for } \\
\text { Equality of Variances }\end{array}$} & \multicolumn{7}{|c|}{ t-test for Equality of Means } \\
\hline & & \multirow[b]{2}{*}{$\mathrm{F}$} & \multirow[b]{2}{*}{ Sig. } & \multirow[b]{2}{*}{$t$} & \multirow[b]{2}{*}{ df } & \multirow[b]{2}{*}{ Sig. (2-tailed) } & \multirow{2}{*}{$\begin{array}{c}\text { Mean } \\
\text { Difference }\end{array}$} & \multirow{2}{*}{$\begin{array}{l}\text { Std. Error } \\
\text { Difference }\end{array}$} & \multicolumn{2}{|c|}{$\begin{array}{l}95 \% \text { Confidence } \\
\text { Interval of the } \\
\text { Difference }\end{array}$} \\
\hline & & & & & & & & & Lower & Upper \\
\hline Cultural Empathy & $\begin{array}{l}\text { Equal variances } \\
\text { assumed } \\
\text { Equal variances } \\
\text { not assumed }\end{array}$ & 17.391 & .000 & $\begin{array}{l}4.046 \\
4.296\end{array}$ & $\begin{array}{r}338 \\
334.785\end{array}$ & $\begin{array}{l}.000 \\
.000\end{array}$ & $\begin{array}{l}.593 \\
.593\end{array}$ & $\begin{array}{l}.147 \\
.138\end{array}$ & $\begin{array}{l}.305 \\
.322\end{array}$ & $\begin{array}{l}.881 \\
.865\end{array}$ \\
\hline $\mathrm{OM}$ & $\begin{array}{l}\text { Equal variances } \\
\text { assumed } \\
\text { Equal variances } \\
\text { not assumed }\end{array}$ & 30.731 & .000 & $\begin{array}{l}-1.909 \\
-1.793\end{array}$ & $\begin{array}{r}338 \\
227.146\end{array}$ & $\begin{array}{l}.057 \\
.074\end{array}$ & $\begin{array}{l}-.257 \\
-.257\end{array}$ & $\begin{array}{l}.135 \\
.144\end{array}$ & $\begin{array}{l}-.523 \\
-.540\end{array}$ & $\begin{array}{l}.008 \\
.026\end{array}$ \\
\hline ES & $\begin{array}{l}\text { Equal variances } \\
\text { assumed } \\
\text { Equal variances } \\
\text { not assumed }\end{array}$ & 55.165 & .000 & $\begin{array}{l}3.384 \\
3.720\end{array}$ & $\begin{array}{r}338 \\
334.614\end{array}$ & $\begin{array}{l}.001 \\
.000\end{array}$ & $\begin{array}{l}.547 \\
.547\end{array}$ & $\begin{array}{l}.162 \\
.147\end{array}$ & $\begin{array}{l}.229 \\
.258\end{array}$ & $\begin{array}{l}.864 \\
.836\end{array}$ \\
\hline SI & $\begin{array}{l}\text { Equal variances } \\
\text { assumed } \\
\text { Equal variances } \\
\text { not assumed }\end{array}$ & 34.882 & .000 & $\begin{array}{l}3.711 \\
4.076\end{array}$ & $\begin{array}{r}338 \\
334.989\end{array}$ & $\begin{array}{l}.000 \\
.000\end{array}$ & $\begin{array}{l}.868 \\
.868\end{array}$ & $\begin{array}{l}.234 \\
.213\end{array}$ & $\begin{array}{l}.408 \\
.449\end{array}$ & $\begin{array}{l}1.328 \\
1.286\end{array}$ \\
\hline $\mathrm{F}$ & $\begin{array}{l}\text { Equal variances } \\
\text { assumed } \\
\text { Equal variances } \\
\text { not assumed }\end{array}$ & 12.536 & .000 & $\begin{array}{l}-.673 \\
-.687\end{array}$ & $\begin{array}{r}338 \\
308.417\end{array}$ & $\begin{array}{l}.501 \\
.493\end{array}$ & $\begin{array}{l}-.086 \\
-.086\end{array}$ & $\begin{array}{l}.127 \\
.125\end{array}$ & $\begin{array}{l}-.337 \\
-.332\end{array}$ & $\begin{array}{l}.165 \\
.160\end{array}$ \\
\hline Satisfaction w ith life & $\begin{array}{l}\text { Equal variances } \\
\text { assumed } \\
\text { Equal variances } \\
\text { not assumed }\end{array}$ & 1.254 & .264 & $\begin{array}{l}6.156 \\
6.084\end{array}$ & $\begin{array}{r}338 \\
277.672\end{array}$ & $\begin{array}{l}.000 \\
.000\end{array}$ & $\begin{array}{l}.289 \\
.289\end{array}$ & $\begin{array}{l}.047 \\
.047\end{array}$ & $\begin{array}{l}.196 \\
.195\end{array}$ & $\begin{array}{l}.381 \\
.382\end{array}$ \\
\hline physical health & $\begin{array}{l}\text { Equal variances } \\
\text { assumed } \\
\text { Equal variances } \\
\text { not assumed }\end{array}$ & 9.874 & .002 & $\begin{array}{l}2.288 \\
2.434\end{array}$ & $\begin{array}{r}338 \\
335.413\end{array}$ & $\begin{array}{l}.023 \\
.015\end{array}$ & $\begin{array}{l}.163 \\
.163\end{array}$ & $\begin{array}{l}.071 \\
.067\end{array}$ & $\begin{array}{l}.023 \\
.031\end{array}$ & $\begin{array}{l}.304 \\
.295\end{array}$ \\
\hline psychological health & $\begin{array}{l}\text { Equal variances } \\
\text { assumed } \\
\text { Equal variances } \\
\text { not assumed }\end{array}$ & 13.525 & .000 & $\begin{array}{l}-.428 \\
-.462\end{array}$ & $\begin{array}{r}338 \\
337.999\end{array}$ & $\begin{array}{l}.669 \\
.644\end{array}$ & $\begin{array}{l}-.0265 \\
-.0265\end{array}$ & $\begin{array}{l}.0619 \\
.0573\end{array}$ & $\begin{array}{l}-.1482 \\
-.1392\end{array}$ & $\begin{array}{l}.0953 \\
.0862\end{array}$ \\
\hline social support & $\begin{array}{l}\text { Equal variances } \\
\text { assumed } \\
\text { Equal variances } \\
\text { not assumed }\end{array}$ & 115.392 & .000 & $\begin{array}{l}.437 \\
.470\end{array}$ & $\begin{array}{r}338 \\
337.828\end{array}$ & $\begin{array}{l}.662 \\
.638\end{array}$ & $\begin{array}{l}.022 \\
.022\end{array}$ & $\begin{array}{l}.051 \\
.047\end{array}$ & $\begin{array}{l}-.078 \\
-.071\end{array}$ & $\begin{array}{l}.123 \\
.116\end{array}$ \\
\hline job satisfaction & $\begin{array}{l}\text { Equal variances } \\
\text { assumed } \\
\text { Equal variances } \\
\text { not assumed }\end{array}$ & 7.642 & .006 & $\begin{array}{l}.031 \\
.029\end{array}$ & $\begin{array}{r}338 \\
243.143\end{array}$ & $\begin{array}{l}.975 \\
.977\end{array}$ & $\begin{array}{l}.002 \\
.002\end{array}$ & $\begin{array}{l}.056 \\
.058\end{array}$ & $\begin{array}{l}-.108 \\
-.113\end{array}$ & $\begin{array}{l}.111 \\
.116\end{array}$ \\
\hline
\end{tabular}

Note: In Table 3, for the analysis purpose, "0" denotes Males and " 1 " denotes Females. 
Table 5: Correlations

Correlations

\begin{tabular}{|c|c|c|c|c|c|c|c|c|c|c|c|c|}
\hline & & $\begin{array}{l}\text { Cultural } \\
\text { Empathy }\end{array}$ & $\mathrm{OM}$ & ES & SI & $\mathrm{F}$ & $\begin{array}{c}\text { Satisfaction } \\
\text { with life }\end{array}$ & $\begin{array}{c}\text { physical } \\
\text { health }\end{array}$ & $\begin{array}{c}\text { psychological } \\
\text { health }\end{array}$ & social support & $\begin{array}{c}\text { job } \\
\text { satisfaction }\end{array}$ & Age \\
\hline \multirow[t]{3}{*}{ Cultural Empathy } & Pearson Correlation & 1 & $.221^{* *}$ & $.378^{* *}$ & $.325^{* *}$ & .081 & $.781^{\star \star *}$ & .055 & $.306^{* *}$ & $.204^{* *}$ & $.131^{*}$ & -.070 \\
\hline & Sig. (2-tailed) & & .000 & .000 & .000 & .138 & .000 & .310 & .000 & .000 & .015 & .201 \\
\hline & $\mathrm{N}$ & 340 & 340 & 340 & 340 & 340 & 340 & 340 & 340 & 340 & 340 & 340 \\
\hline \multirow[t]{3}{*}{$\mathrm{OM}$} & Pearson Correlation & $.221^{* *}$ & 1 & $.283^{* *}$ & $.210^{* *}$ & $.429^{* *}$ & $.303^{* *}$ & $-.116^{*}$ & $-.114^{\star}$ & $.192^{* *}$ & $.136^{*}$ & -.098 \\
\hline & Sig. (2-tailed) & .000 & & .000 & .000 & .000 & .000 & .033 & .036 & .000 & .012 & .070 \\
\hline & $\mathrm{N}$ & 340 & 340 & 340 & 340 & 340 & 340 & 340 & 340 & 340 & 340 & 340 \\
\hline \multirow[t]{3}{*}{ ES } & Pearson Correlation & $.378^{* *}$ & $.283^{\star \star x}$ & 1 & -.105 & $-.346^{\star \star}$ & $.296^{\star *}$ & -.007 & $-.311^{\star \star}$ & $-.371^{\star \star}$ & $-.121^{*}$ & $-371^{* *}$ \\
\hline & Sig. (2-tailed) & .000 & .000 & & .054 & .000 & .000 & .901 & .000 & .000 & .026 & .000 \\
\hline & $\mathrm{N}$ & 340 & 340 & 340 & 340 & 340 & 340 & 340 & 340 & 340 & 340 & 340 \\
\hline \multirow[t]{3}{*}{$\mathrm{SI}$} & Pearson Correlation & $.325^{\star \star}$ & $.210^{* *}$ & -.105 & 1 & $.169^{* *}$ & $.514^{* *}$ & -.033 & $.581^{\star *}$ & $.178^{\star \star}$ & -.012 & $-.127^{*}$ \\
\hline & Sig. (2-tailed) & .000 & .000 & .054 & & .002 & .000 & .538 & .000 & .001 & .821 & .019 \\
\hline & $\mathrm{N}$ & 340 & 340 & 340 & 340 & 340 & 340 & 340 & 340 & 340 & 340 & 340 \\
\hline \multirow[t]{3}{*}{$\mathrm{F}$} & Pearson Correlation & .081 & $.429^{\star \star}$ & $-.346^{\star *+}$ & $.169^{* *}$ & 1 & .091 & .050 & $.156^{\star \star *}$ & $.865^{\star *}$ & $.266^{* *}$ & $.297^{\star \star n}$ \\
\hline & Sig. (2-tailed) & .138 & .000 & .000 & .002 & & .095 & .358 & .004 & .000 & .000 & .000 \\
\hline & $\mathrm{N}$ & 340 & 340 & 340 & 340 & 340 & 340 & 340 & 340 & 340 & 340 & 340 \\
\hline \multirow[t]{3}{*}{ Satisfaction w ith life } & Pearson Correlation & $.781^{\star *}$ & $.303^{* *}$ & $.296 *$ & $.514^{* *}$ & .091 & 1 & .098 & .103 & .012 & -.030 & .058 \\
\hline & Sig. (2-tailed) & .000 & .000 & .000 & .000 & .095 & & .070 & .057 & .832 & .578 & .283 \\
\hline & $\mathrm{N}$ & 340 & 340 & 340 & 340 & 340 & 340 & 340 & 340 & 340 & 340 & 340 \\
\hline \multirow[t]{3}{*}{ physical health } & Pearson Correlation & .055 & $-.116^{*}$ & -.007 & .033 & .050 & .098 & 1 & -.029 & -.074 & .027 & $.204^{* *}$ \\
\hline & Sig. (2-tailed) & .310 & .033 & .901 & .538 & .358 & .070 & & .594 & .174 & .614 & .000 \\
\hline & $\mathrm{N}$ & 340 & 340 & 340 & 340 & 340 & 340 & 340 & 340 & 340 & 340 & 340 \\
\hline \multirow[t]{3}{*}{ psychological health } & Pearson Correlation & $.306^{* *}$ & $-.114^{\star}$ & $-.311^{*+}$ & $.581^{\star *}$ & $.156^{* *}$ & .103 & -.029 & 1 & $.349^{* *}$ & $.334^{* *}$ & -.034 \\
\hline & Sig. (2-tailed) & .000 & .036 & .000 & .000 & .004 & .057 & .594 & & .000 & .000 & .535 \\
\hline & $\mathrm{N}$ & 340 & 340 & 340 & 340 & 340 & 340 & 340 & 340 & 340 & 340 & 340 \\
\hline \multirow[t]{3}{*}{ social support } & Pearson Correlation & $.204^{\star \star}$ & $.192^{\star \star}$ & $-.371^{\star *}$ & $.178^{\star *}$ & $.865^{\star \star}$ & .012 & -.074 & $.349^{\star \star}$ & 1 & $.386^{*+}$ & $.192^{*+}$ \\
\hline & Sig. (2-tailed) & .000 & .000 & .000 & .001 & .000 & .832 & .174 & .000 & & .000 & .000 \\
\hline & $\mathrm{N}$ & 340 & 340 & 340 & 340 & 340 & 340 & 340 & 340 & 340 & 340 & 340 \\
\hline \multirow[t]{3}{*}{ job satisfaction } & Pearson Correlation & $.131^{*}$ & $.136^{\star}$ & $-.121^{*}$ & .012 & $.266^{* *}$ & -.030 & .027 & $.334^{\star \star}$ & $.386^{\star \star}$ & 1 & $-.337^{*+}$ \\
\hline & Sig. (2-tailed) & .015 & .012 & .026 & .821 & .000 & .578 & .614 & .000 & .000 & & .000 \\
\hline & $\mathrm{N}$ & 340 & 340 & 340 & 340 & 340 & 340 & 340 & 340 & 340 & 340 & 340 \\
\hline \multirow[t]{3}{*}{ Age } & Pearson Correlation & -.070 & -.098 & $-.371^{* *}$ & $-.127^{*}$ & $.297^{* *}$ & .058 & $.204^{* \star}$ & -.034 & $.192^{\star \star}$ & $-.337^{\star \star}$ & 1 \\
\hline & Sig. (2-tailed) & .201 & .070 & .000 & .019 & .000 & .283 & .000 & .535 & .000 & .000 & \\
\hline & $\mathrm{N}$ & 340 & 340 & 340 & 340 & 340 & 340 & 340 & 340 & 340 & 340 & 340 \\
\hline
\end{tabular}

${ }^{* *}$. Correlation is significant at the 0.01 level (2-tailed).

*. Correlation is significant at the 0.05 level (2-tailed). 